\title{
The Comparative Effects Of Chemical Mutagen And Hybridization To Get Genetic Variation In Bread Wheat (Triticum aestivum L.).
}

\author{
Ahmed, B.H. and Ahmed, H.A.* \\ Agronomy Dep., Fac. of Agric., Al-Azhar Univ., Assiut, Egypt. \\ *Corresponding auther email: dr.hagagy84@ yahoo.com
}

Received on: 11/11/2020

Accepted on: 1/12/2020

\begin{abstract}
In an attempt to develop for high yield genotypes of bread wheat, two procedures, i.e. mutation breeding and hybridization were used to induce new genetic variations. Three field experiments were conducted during the seasons 2017/2018, 2018/2019 and 2019/2020, at the Experimental Farm, Faculty of Agriculture, Al-Azhar University Assiut Branch. The results showed that, hybridization and treated plants by $2000 \mathrm{ppm}$ of hydrazine hydrate were the more effective than other treatment of hydrazine hydrate, as well as the hybrids were more responsible than the other genotypes for induction of stable promising mutants according to final results at $F_{2}$ and $F_{2} M_{2}$ generation especially grain yield /plant. The $F_{2}$ and $\mathrm{M}_{2}$ populations of these genotypes exhibited differences in the magnitude of phenotypic (PCV) and genotypic (GCV) coefficient of variation and heritability for studied traits under this study. The highest expected gain from selection (GA\%) for grain yield/plant was obtained from Sids-14, Gemmiza 11 and Sids 14 x Giza 171 when treated by 2000 ppm from Hydrazine hydrate reached to $77.80,57.70$ and $55.71 \%$, respectively., more than those of the untreated $F_{2}$ populations.
\end{abstract}

KEYWORDS: wheat, mutation breeding, hybridization, phenotypic and genotypic of variability, heritability, genetic advance.

\section{INTRODUCTION}

Wheat (Triticum aestivum L.) is the most widely grown cereal crop in the world and one of the central pillars of global food security. About 651 to 730.3 million tons of wheat was produced from 217 million hectares in 2010 and 2017/2018 with productivity level of $3 \mathrm{t} / \mathrm{ha}$ (FAO (2010)). Wheat is an important food crops of the world. It is a dietary mainstay for millions of people as it provides $50 \%$ caloric and protein requirements to a major population of the world.

The prime strategy in mutation breeding has been to upgrade the well adapted plant varieties by altering one or two major traits which limit their productivity or enhance their quality. The genetic variability resulted from micro- mutation allows breeding of quantitative characters (Brojevic (1965)). Sarkar (1986) indicated that estimated variation of the quantitative characters were higher for the $\mathrm{M}_{3}$ generation than those of the M2 generation. Chemical mutagenesis is regarded as in effective and important tool in improving the yield and quality characters of crop plants .In alkylating agents are very effective mutagens in higher plants. Lately, the importance of mutagenesis in increasing the recombinations rate with possibility of adding induced variability to the inheritance in a cross has been realized and heterozygous genotypes of different crop species have been exposed to mutagens. Artificial induction of mutations by using of chemical mutagens such as radiation and chemicals are considered to be one of the useful tools for plant improvement by increasing of genetic variability in many plant species, especially the self-fertilized plants. (Sakin 2002), Srivastava et al (2011). Fatima and Al-Shamma (2015), Okaz et al (2016) and Al-Shamma and Mohammed (2018).

Hybridization is the principal breeding procedure for inducing genetic variability in wheat. The chief role of hybrid to cross divers genotypes to create hybrid populations with wide genetic variation from which new recombinations of genetic selected ( Singh (2000), Khadr and shukry (1972) and Gupta and Virk (1997)) reported that the variations induced by irradiation ,EMS and hybridization were not always cumulative.

The main objective of the present investigation is to comparative effect of (HZ) and hybridization to create genetic variation in bread wheat.

\section{MATERIALS AND METHODS}




\section{Ahmed, B.H. and Ahmed, H.A., 2020}

The present study was carried out at the Experimental Farm Faculty of Agriculture, Al-Azhar University Assiut Branch, during the successive growing seasons of 2017/2018, 2018/2019 and 2019/2020. Three bread wheat (Triticum aestivum L.) cultivars were used. The name and pedigree of this parents are showed in Table1. In the 2017/2018 season two crosses were made among the parents to produce $F_{1}$ hybrid grains.

Table 1. Pedigree and origin of cultivars and /or lines used in the two bread wheat crosses in this study. Parent

Pedigree

\begin{tabular}{cc}
\hline P1 & Sids- 14 \\
P2 & giza-171 \\
P2 & Gemmiza 11
\end{tabular}

Pedigree
BOW"S"/Vee"S"//Bow"S"/TSI/3/Beni Sweef 1
SD293-1SD-2SD-4SD- Osd
Sakha93 / Gemmiza 9
BOW"S"/KVZ"S"//7C/SERI-82/3/GIZA 168/SAKHA 61
GM7892-2GM-1GM-2GM-1GM-0GM

In the 2018/2019 season some $F_{1}$ and parental seeds were planted. Self-pollination was made for $F_{1}$ crosses. The seeds of all studied populations $\left(\mathrm{P}_{1}, \mathrm{P}_{2}\right.$ and $\mathrm{F} 1$ ) were randomly divided in two equal groups. The first group and $\mathrm{F}_{2}$ was normally planted without any treatment. The second group of seeds was soaked for 24 hours before planting in 1000 and $2000 \mathrm{ppm}$ solution from (HZ) for two $\mathrm{F}_{1}$ crosses namely ., Sids 14 x Gemmiza11 and Sids 14 x Giza 171. These treated populations represented the $\mathrm{M}_{1}$ generations. The genotypes were treated as follows:

Two control $\mathrm{F}_{2}$ (Sids $14 \times$ Gemmiza 11 and Sids14 x Giza 171), four $\mathrm{F}_{2} \mathrm{M}_{2}$ (Sids14 x Gemmiza 11 (1000ppm HZ), Sids14 x Gemmiza 11(2000ppm HZ), Sids14 x Giza 171(1000ppm HZ) and Sids14 x Giza 171 (2000ppm HZ), six treated parents i.e. Sids 14(1000ppm HZ), Sids 14(2000ppm HZ), Gemmiza 11(1000ppm HZ), Gemmiza 11(2000ppm HZ), Giza
171 (1000ppm HZ) and Giza 171 (2000ppm HZ) which were grown during season 2019/2020. From each population was grown in a plot size of $12.5 \mathrm{~m} \mathrm{x}$ $5 \mathrm{~m}$. From each population about 100 plants were randomly selected for recording observations on six quantitative characters viz., days to $50 \%$ heading (D.F), plant height $(\mathrm{PH})(\mathrm{cm})$, number of spikes / plant $(\mathrm{S} / \mathrm{P})$, number of kernels / spike (K/S), 100kernel weight $(100-\mathrm{Wg})(\mathrm{g})$ and grain yield / plant (G.Y/P) (gm) . Plants which have grain yield higher than the control treatments by $20-50 \%$ considered as mutant $\left(\mathrm{M}_{1}\right)$. The data were subjected to statistical analysis and various genetic parameters such as phenotypic (PCV) and genotypic (GCV) coefficient variation, heritability $\left(h_{b}\right)$, genetic advance were calculated According Johnson et al (1955) and Allard (1960).

Table 2. The analysis of variance and expected mean squares:-

\begin{tabular}{lllll}
\hline Source of variance & D.F & M.S & \multicolumn{2}{l}{ Expected mean square } \\
\cline { 4 - 5 } & & & Variance & Covariance \\
\hline Replications & $\mathrm{r}-1$ & $\mathrm{M}_{3}$ & $\sigma^{2} \mathrm{e}+\mathrm{g} \sigma^{2} \mathrm{r}$ & \\
Genotypes & $\mathrm{g}-1$ & $\mathrm{M}_{2}$ & $\sigma^{2} \mathrm{e}+\mathrm{r} \sigma^{2} \mathrm{~g}$ & Cov.e $+\mathrm{r}$ Cov.g \\
Error & $(\mathrm{r}-1)(\mathrm{g}-1)$ & $\mathrm{M}_{1}$ & $\sigma^{2} \mathrm{e}$ & Cov.e \\
\hline
\end{tabular}

Where: $r$ and $g$ are number of replications and genotypes, respectively.

$\sigma^{2}$ e and cov.e are error variance and covariance, respectively and $\sigma^{2} \mathrm{~g}$ and cov.g are genetic variance and covariance, respectively.

*** Heritability in broad sense was calculated as follow:

Heritability in $\mathrm{F}_{2}$ and $\mathrm{M}_{2}(\mathrm{H})=\left(\sigma^{2} \mathrm{~g} / \sigma^{2} \mathrm{p}\right) \times 100$

\subsection{Expected gain from selection (GA\%)}

The expected genetic advance (GA) expressed as a percentage of the mean value with an assumed 5\% intensity of selection pressure was computed by the formula given by Johnson et al (1955) and Allard (1960).

as: $(\mathrm{GA} \%)=k \cdot \mathrm{H}^{\sqrt{\sigma^{2} P}}$
Where: $k=2.06$ constant for $20 \%$ selection intensity (i.e. the highest-performing $5 \%$ are selected), respectively.

$\mathrm{H}=$ broad-sense heritability and $\sigma^{2} \mathrm{P}=$ Phenotypic variance of the population.

The phenotypic and genotypic coefficients of variation are computed as follow Burton (1952).

$$
\begin{aligned}
& P C V=(\sqrt{V P} / \bar{X}) 100 \\
& G C V=(\sqrt{V G} / \bar{X}) 100
\end{aligned}
$$

Where: PCV, GCV are phenotypic and genotypic coefficients of variation, respectively; VP, VG are corresponding variances; and $\bar{X}$ is the population mean the relative values of these two types of coefficients give an idea about the magnitude of 
Scientific Journal of Agricultural Sciences 2 (2): 00-00, 2020

variability presented in a population. Interpretation of variability in terms is given below (Singh and Singh, 1975).

\section{RESULTS AND DiISSECTION}

The obtained results of the present investigation well be presented in three parts as follows:

1 - Means and variances of the different studied characters for the untreated and HZ treated groups. Each group included $\mathrm{P}_{1}{ } \mathrm{P}_{2} 6 \mathrm{~F}$ and $\mathrm{F}_{r}$ populations of an inetrspecific cross between the three bread wheat varieties (Sids I $\leqslant$, Gemmiza $\ \backslash$ and Giza 171). 2-PCV , GCV and heritability estimates .

3-The response to selection with respect to the studied characters.

Table 3. Estimates of genetic parameters for difference quanetitive characters in $M_{1}, F_{1}$ and $F_{1} M_{1}$ populations in bread wheat.

\begin{tabular}{|c|c|c|c|c|c|c|}
\hline \multirow{2}{*}{$\underbrace{\text { Traits }}_{\text {Genotypes }}$} & \multicolumn{2}{|c|}{ Days to heading 50\% } & \multicolumn{2}{|c|}{ Plant height } & \multicolumn{2}{|c|}{ Number of spike/ plant } \\
\hline & mean & Cv\% & mean & $\mathrm{Cv} \%$ & Mean & $\mathrm{Cv} \%$ \\
\hline Sids 14(1000) & 88.2 & 2.25 & 128.3 & 5.45 & 14.7 & 12.85 \\
\hline Sids 14(2000) & 90.45 & 2.11 & 122.85 & 5.50 & 11.3 & 20.39 \\
\hline Giza $171(1000)$ & 96.50 & 9.00 & 114.1 & 7.07 & 12.3 & 15.44 \\
\hline G 171 (2000) & 101.40 & 3.53 & 104.30 & 13.66 & 11.35 & 34.6 \\
\hline Sids 14 X G 171 & 89.85 & 2.06 & 118.12 & 5.60 & 13.55 & 16.84 \\
\hline Sids 14 X Giza 171(1000) & 90.4 & 1.61 & 120.60 & 5.95 & 13.35 & 18.58 \\
\hline Sids 14 X G 171(2000) & 95.45 & 3.96 & 116.95 & 6.48 & 12.65 & 12.59 \\
\hline Gemmiza 11 (1000) & 86.15 & 2.41 & 107.65 & 4.23 & 5.20 & 19.79 \\
\hline Gemmiza 11 (2000) & 88.8 & 1.15 & 120.8 & 4.47 & 10.05 & 26.60 \\
\hline Sids 14 X Gemmiza 11 & 88.5 & 3.67 & 109.65 & 9.81 & 12.90 & 19.20 \\
\hline $\begin{array}{c}\text { Sids } 14 \text { X Gemmiza } \\
11(1000)\end{array}$ & 95.37 & 7.48 & 99.6 & 5.68 & 7.45 & 19.67 \\
\hline $\begin{array}{c}\text { Sids 14 X } \\
\text { Gemmiza11(2000) }\end{array}$ & 101.72 & 1.53 & 101.9 & 17.54 & 9.17 & 43.31 \\
\hline Sids 14 & 88.15 & 2.06 & 110.05 & 2.49 & 12.65 & 10.68 \\
\hline Giza 171 & 90.10 & 8.00 & 114.31 & 4.53 & 10.95 & 10.98 \\
\hline Gemmiza 11 & 86.35 & 2.40 & 108.55 & 3.98 & 11.7 & 9.00 \\
\hline
\end{tabular}

Table 3. Continued.

\begin{tabular}{|c|c|c|c|c|c|c|}
\hline \multirow{2}{*}{$\overbrace{\text { Genotypes }}^{\text {Traits }}$} & \multicolumn{2}{|c|}{ Number of kerlines/ spike } & \multicolumn{2}{|c|}{ 100-grain wheight } & \multicolumn{2}{|c|}{ Grain yield / plant } \\
\hline & Mean & $\mathrm{Cv} \%$ & mean & $\mathrm{Cv} \%$ & mean & $\mathrm{Cv} \%$ \\
\hline Sids 14(1000) & 74.10 & 19.94 & 5.18 & 13.25 & 50.37 & 28.02 \\
\hline Sids 14(2000) & 64.60 & 16.42 & 5.05 & 9.42 & 49.62 & 34.18 \\
\hline Giza $171(1000)$ & 62.20 & 13.63 & 5.64 & 13.09 & 40.88 & 18.84 \\
\hline G 171 (2000) & 73.30 & 15.60 & 6.08 & 9.66 & 45.36 & 28.56 \\
\hline Sids 14 X G 171 & 60.50 & 14.45 & 4.28 & 9.24 & 51.00 & 16.59 \\
\hline Sids 14 X Giza $171(1000)$ & 70.95 & 13.36 & 5.50 & 8.31 & 43.70 & 29.15 \\
\hline Sids 14 X G 171(2000) & $\mathbf{7 4 . 4 7}$ & 20.76 & 5.31 & 9.31 & 51.13 & 13.35 \\
\hline Gemmiza 11 (1000) & 68.65 & 15.17 & 5.55 & 12.47 & 40.12 & 26.63 \\
\hline Gemmiza 11 (2000) & 70.10 & 10.46 & 6.05 & 8.78 & 54.37 & 23.25 \\
\hline Sids 14 X Gemmiza 11 & $\mathbf{5 7 . 4 0}$ & 13.57 & 5.13 & 10.40 & 36.65 & 22.97 \\
\hline $\begin{array}{c}\text { Sids } 14 \text { X Gemmiza } \\
11(1000)\end{array}$ & 83.10 & 16.00 & 5.22 & 8.39 & 50.85 & 33.63 \\
\hline $\begin{array}{c}\text { Sids 14X } \\
\text { Gemmiza11(2000) }\end{array}$ & 79.10 & 10.27 & 5.04 & 11.17 & 49.97 & 33.38 \\
\hline Sids 14 & 64.40 & 8.04 & 4.93 & 4.06 & 38.59 & 2.79 \\
\hline Giza 171 & 56.75 & 8.41 & 4.39 & 8.80 & 30.90 & 7.82 \\
\hline Gemmiza 11 & $\mathbf{5 7 . 0 5}$ & 8.75 & 3.96 & 4.54 & 36.78 & 9.08 \\
\hline
\end{tabular}

It's clear from C.V\% values, presence of great variations among obtained data, as indicator to effect treatments on genotypes. Means of the $\mathrm{P}_{1}, \mathrm{P}_{2}, \mathrm{~F}_{1}$ and $\mathrm{F}_{2}$ populations in the two seasons for the characters studied are presented in Table 3 . With respect to HZ treatments, there are clear differences among all population means for all traits except for days to 50 $\%$ to heading, all populations means were late or equal with untreated parents means. In connection with remain studied characters, populations means gave significant or noticed differences.

These results are in according with those Ahmad (2011), Khan and verma (2015) and Ahmad (2019). 


\section{2. $\mathrm{M}_{2}$ generation}

Analysis of variance and means in second seasons.

The significant of variance components obtained from the analysis of variance for all the studied characters in the bread wheat mutated populations of the $\mathrm{M}_{2}$ generation is presented in Table 4.

With respect to days to $50 \%$ heading, the genotype Giza171 (1000and 2000 ppm) was the earliest populations.

Also, $\mathrm{HZ}$ treatments increased clearly the amount of variation (as a percentage) of plant height of all the studied genotypes, but number of spikes per plant had changed significantly of Sids 14(1000), Gemmiza 11 (2000) and Sids 14 X Gemmiza .

Concerning number of kernels per spike, appearance and genetic changes were clear and noticed on all genotypes except cross Sids $14 \mathrm{X}$ Gemmiza 11.

In connection with 100 - grain weigh, all genotypes were high except Sids 14(2000), G 171 (1000), Sids 14 X G 171 and Sids 14 X Gem 11(1000).

With respect to grain yield per plant, all genotypes gave noticed high means except Sids 14(1000) and Sids 14(2000).

These results are in according with those Sakin (2002), Ahmad (2011), Khan and verma(2015), Balkan (2018) and Ahmed (2019).

The phenotypic coefficient (PCV) of variability values were higher than (GCV) for all studied traits in the two crosses (Table 4). The phenotypic and genotypic coefficient variabilities were low for days to $50 \%$ heading in all derived populations.

For plant height, it is clear in Table 4, there are many variations in plant height of genotypes. The effect of $1000 \mathrm{ppm}$ and 2000 PPM from HZ was highly as compared with control. All genotypes gave average values except G 171 (2000) and Sids 14 X Giza 171(1000) were short. This results coincides with Hanafy et al (2006), Ahmad (2011), Hawash and Al-Shamma (2016), and Al-Shamma and Mohammed (2018) found that the lowest plant height was obtained when exposed the seedlings to external electric field, sodium azide and heat shock.

The PCV and GCV were low for plant height in all derived populations except Giza 171(2000ppm) had highest values. The obtained results are in accordance with those obtained by Sakin (2002), Zaazaa et al (2012) and Balkan (2018).

With respect to number of spikes /plant, The highest number of spikes /plant (13.26 and 12.87) were obtained from Sids 14 (HZ), (1000ppm) and $\mathrm{x}$ Gemmiza 11 (HZ), (2000 ppm) . This results coincides with Ahmad (2011) and Hawash and AlShamma (2016) when used electric shock on wheat.

There were high to moderate phenotypic and genotypic coefficient variabilities for number of spike /plant in all derived populations. Mutant Sids 14 hydrazine hydrate $(1000 \mathrm{ppm})$ surpassed original plants in number of spike per plant with $21.5 \%$. This considered

genetic variability accompanied with high heritability estimates, this occurred in the 1000ppm concentrate M2 populations of Sids 14 The obtained results are in accordance with those obtained by Sobieh (1999) and Khan and Verma (2015) when used gamma rays on wheat.

Concerning number of kernels per spike, the differences in the mean values due to genotypes effect were high in $\mathrm{F}_{2} \mathrm{M}_{2}$ and $\mathrm{M}_{2}$ generation. The treatments of $\mathrm{HZ}$ were effective either from $1000 \mathrm{ppm}$ or 2000pp except untreated cross Sids 14 X Gemmiza 11.

There were moderate phenotypic and genotypic coefficient variabilities for number of kernels per spike in all derived populations (Table 4). The obtained results are in accordance with those obtained by Khan and Verma (2015) and Balkan (2018) when used gamma rays on wheat.

All plants which maintain the mutations until M2 were surpassed untreated plants in 100-grain weight. The highest 100-grain weight $(5.82,5.63$ and $5.47 \mathrm{~g})$ was obtained from Gemmiza 11 (HZ 2000ppm), Sids 14 x Gemmiza 11 (HZ 2000ppm) and Sids 14 x Giza 171 (HZ 2000ppm) but untreated plant Sids 14 x Giza 171 gave 4.43g Sids14 x Gemmiza 11 gave $4,91 \mathrm{~g}$. So, the increasing percentage from untreated plants was $18.53,14.66$ and $13.25 \%$, respectively.

The phenotypic and genotypic coefficient variabilities were moderate for 100-grain weight in all derived populations except Giza 171 (2000ppm) was low. The obtained results are in accordance with those obtained by Balkan (2018).

Regarding grain yield / plant, all plants which maintain the mutations until $\mathrm{M}_{2}$ were surpassed untreated plants. The highest value of means was (41.91g)) obtained from Sids14 x Gemmiza 11 (HZ $2000 \mathrm{ppm})$ So, the increasing percentage from untreated plants was $22.18 \%$, but the $\mathrm{F}_{2}$ (Sids14 $\mathrm{x}$ Giza 171) population was higher than the all treatments of $\mathrm{F}_{2} \mathrm{M}_{2}$ and $\mathrm{M}_{2}$ populations. This result coincides with Dhole et al. (2003), Ahmad (2011), Al-Shammaa (2014), Okaz et al. (2016) and Ahmed (2019). On the other hand, Sobieh (1999) found that no significant effect on mean values of yield and most of its components in $\mathrm{M}_{2}$ generation when used gamma rays in wheat.

The PCV was generally higher than the GCV for all genotypes. High PCV and GCV values were observed for grain yield/plant and yield components 
in $\mathrm{F}_{2}, \mathrm{M}_{2}$, and $\mathrm{F}_{2} \mathrm{M}_{2}$ population .These results indicate that both hybridization among parents and $\mathrm{HZ}$ treatments are capable of creating genetic variability in grin yield per plant , 100- grain weight, number of spike/plant and number of kernels/spike which could be used to improve this important characters. Therefore, these traits were highly affected by environmental factors. The obtained results are in accordance with those obtained by Khan and Verma (2015) and Zaazaa et al (2012). It can say the effectiveness of selection based on the phenotype performance for the characters in the early mutant generations. Zaazaa et al (2012) obtained the lowest number of grains /spike in value PCV and GCV coefficient variabilities. Mahantashivayogayya et al. (2003) found that the highest genetic advance from selection was observed in EMS treated populations for grains per spike and 1000-grain weight.

Khadr and Shukry (1972) reported that the relative magnitude of induced variation compared with that from hybridization depended on the particular mutagen and characters, and averaged less than $50 \%$ percent of that from hybridization. . Heritabilities and expected genetic gains were not much lower in mutagenic populations than in hybrid populations. The induced variation was not accompanied by any shift in the population mean in most cases, variation was equally distributed around the population mean. Reddy and Revathi (1992) found that the mutation frequency increased with duration, concentration of the mutagen treatment, and it was higher when treating seeds of barley and wheat individually and in combination with gamma ray, 0.5 ethyl methane sulphonate (EMS) and sodium azide.

Heritability values are categorized as low ( 0 $30 \%)$, moderate (30-60\%) and high (60\% and above) as stated by Robinson et al. (1949). Heritability estimates indicate that the progress from selection for plant characters is relatively easy or difficult to make in breeding program. Heritability estimates in broad sense and genetic advance are presented in Table 4. The heritability values in broad sense was high for all studied traits in all populations.

The heritability values in broad sense was moderate for number of kernels /spike in $\mathrm{F}_{2}$ untreated cross1 (Sids 14 x Giza 171).

These results are in accordance with the findings of El- Aref et al. (2011), Amin (2013), Abd El- Rady (2018), Balkan (2018), El-Gammaal and Yahya (2018) and El Massry and El-Nahas (2018). On the other hand, Sakin (2002). Sakin and Yildrim (2004) estimated that the high heritability for mutant

Table 4. Estimates of genetic parameters for difference quanetitive characters in $M_{2}, F_{2}$ and $F_{2} M_{2}$ populations in bread wheat.

\begin{tabular}{cccccccc}
\hline \multirow{2}{*}{ Genotypes } & \multicolumn{9}{c}{ D.F } & & \\
\cline { 2 - 8 } Sids 14(1000) & Mean & VP & VG & PCV & GCV & h $_{\mathbf{b}}$ & GA\% \\
\hline & 98.16 & 3.45 & 3.27 & 1.89 & 1.84 & 94.62 & 3.69
\end{tabular}

populations demonstrated that induced variation was maintained in the $\mathrm{M}_{2}$ and $\mathrm{M}_{3}$ generations. Johnson et al. (1955) advocated that heritability estimates along with genetic advance are usually more helpful than the heritability value alone in predicting the resultant effects of selection. Sobieh and Ragab (2000) reported that high magnitudes of GCV, $\mathrm{h}_{\mathrm{b}}{ }^{2}$. and GA for number of spikes/plant and number of grains/spike were obtained, but moderate magnitude for the weight of grains /spike was found. The high $\mathrm{h}_{\mathrm{b}}{ }^{2}$ and GA indicated the effectiveness of selection for these traits.

According to Johnson et al. (1955) genetic advance as percent of mean classified as low $(<10 \%)$ moderate (10-20\%) and high (>20\%). Expected genetic advance calculated from the $\mathrm{M}_{2}$ generation were moderate to high compared to the controls of both treatments (Table 4). The expected genetic advance values was low in $\mathrm{F}_{2} \mathrm{M}_{2}, \mathrm{M}_{2}$ and $\mathrm{F}_{2}$ untreated population for days to $50 \%$ heading. The expected genetic advance value was moderate to high in all populations for plant height, but highest values were Giza 171 (2000), Sids 14 X Giza 171(2000) and Sids 14 X Gemmiza11(2000).

The expected genetic advance was moderate to higher in hybrid material after mutagen treatments in all derived populations for traits number of spike / plant, number of kernels / spike, 100-kernel weight (gm) and grain yield / plant (gm). These results are in accordance with the findings of Kattab et al (2010), El- Aref et al. (2011), Amin (2013), Abd El- Rady (2018) and El Massry and El-Nahas (2018).Hassan (1993) and Shafey et al (1993) found that the highest genetic advance was obtained for plant height, weight of 1000 grains and grain yield /plant. On the other hand, Balkan (2018) found that the high heritability and genetic advance for plant height, number of grains per spike and grain yield/plant in three mutant generations. Grain yield /plant had the lowest heritability estimate with a relatively low value for genetic advance. Kashif and Khaliq (2004) and AlAzab (2013) found that the highest genetic advance was obtained for grain yield / plant (gm) in $\mathbf{M}_{2}$ generation when used gamma rays and hybridization.

In conclusion, $\mathrm{HZ}$ and hybridization were equally effective for inducing genetic variation in the quantitative traits of wheat. Both agents produced approximately the same amount of heritable variability and were similar for predicted 
Ahmed, B.H. and Ahmed, H.A., 2020

\begin{tabular}{|c|c|c|c|c|c|c|c|}
\hline Sids 14(2000) & 93.95 & 21.61 & 21.15 & 4.94 & 4.89 & 97.84 & 9.97 \\
\hline Giza $171(1000)$ & 88.45 & 5.32 & 5.09 & 2.60 & 2.55 & 95.66 & 5.14 \\
\hline Giza 171 (2000) & 89.80 & 14.126 & 13.75 & 4.18 & 4.12 & 97.33 & 8.39 \\
\hline Sids 14 X Giza 171 & 91.85 & 9.45 & 9.15 & 3.34 & 3.29 & 96.74 & 6.67 \\
\hline Sids 14 X Giza 171(1000) & 100.25 & 19.97 & 19.52 & 4.45 & 4.40 & 97.62 & 8.97 \\
\hline Sids 14 X Giza 171(2000) & 97.92 & 22.35 & 21.88 & 4.82 & 4.77 & 97.88 & 9.73 \\
\hline Gemmiza 11 (1000) & 107.91 & 5.016 & 4.79 & 2.07 & 2.02 & 95.53 & 4.08 \\
\hline Gemmiza 11 (2000) & 108.16 & 9.44 & 9.14 & 2.84 & 2.79 & 96.74 & 5.66 \\
\hline Sids 14 X Gemmiza 11 & 95.82 & 1.037 & 0.935 & 1.06 & 1.00 & 90.18 & 1.97 \\
\hline Sids 14 X Gemmiza11(1000) & 106.17 & 23.68 & 23.19 & 4.58 & 4.53 & 97.94 & 9.34 \\
\hline $\begin{array}{c}\text { Sids 14 X } \\
\text { Gemmiza11 }(2000)\end{array}$ & 99.49 & 2.69 & 2.11 & 1.51 & 1.46 & 93.36 & 2.91 \\
\hline Genotypes & Mean & $\mathbf{V P}$ & VG & $\begin{array}{l}\mathrm{PH} \\
\text { PCV }\end{array}$ & GCV & Hb & GA \% \\
\hline Sids 14(1000) & 113.91 & 14.80 & 14.18 & 3.37 & 3.30 & 95.80 & 6.66 \\
\hline Sids 14(2000) & 119.35 & 62.94 & 62.05 & 6.64 & 6.60 & 98.58 & 13.49 \\
\hline Giza 171 (1000) & 113.26 & 57.15 & 56.28 & 6.67 & 6.62 & 98.47 & 13.53 \\
\hline Giza 171 (2000) & 103.98 & 167.65 & 166.52 & 12.45 & 12.41 & 99.32 & 25.47 \\
\hline Sids 14 X Giza 171 & 108.35 & 110.10 & 109.08 & 9.68 & 9.64 & 99.06 & 19.76 \\
\hline Sids 14 X Giza 171(1000) & 101.15 & 56.05 & 55.18 & 7.80 & 7.33 & 98.45 & 15.01 \\
\hline Sids 14 X Giza 171(2000) & 107.39 & 129.10 & 128.04 & 10.58 & 10.53 & 99.17 & 21.61 \\
\hline Gemmiza 11 (1000) & 108.05 & 21.46 & 20.78 & 4.28 & 4.21 & 96.82 & 8.55 \\
\hline Gemmiza 11 (2000) & 120.52 & 41.36 & 30.62 & 4.64 & 4.59 & 97.61 & 9.34 \\
\hline Sids 14 X Gemmiza 11 & 114.38 & 86.03 & 85.05 & 6.10 & 8.06 & 98.88 & 16.51 \\
\hline Sids 14 X Gemmiza11(1000) & 118.51 & 67.44 & 66.54 & 6.93 & 6.88 & 98.65 & 14.08 \\
\hline $\begin{array}{c}\text { Sids 14 X } \\
\text { Gemmiza11(2000) }\end{array}$ & 112.65 & 137.02 & 135.94 & 10.39 & 10.34 & 99.21 & 21.23 \\
\hline
\end{tabular}

Table 4. Continued.

\begin{tabular}{|c|c|c|c|c|c|c|c|}
\hline \multicolumn{8}{|c|}{$\mathbf{S} / \mathbf{P}$} \\
\hline Genotypes & mean & $\mathbf{V P}$ & VG & PCV & GCV & $\mathbf{h}_{b}$ & GA \% \\
\hline Sids 14(1000) & 13.26 & 7.49 & 6.96 & 20.64 & 19.90 & 93.01 & 39.55 \\
\hline Sids 14(2000) & 10.08 & 5.69 & 5.20 & 23.67 & 22.63 & 91.42 & 44.58 \\
\hline Giza $171(1000)$ & 10.48 & 6.18 & 5.69 & 23.73 & 22.76 & 94.94 & 44.96 \\
\hline Giza 171 (2000) & 9.35 & 13.96 & 13.35 & 39.97 & 39.08 & 95.62 & 78.73 \\
\hline Sids 14 X Giza 171 & 10.91 & 11.94 & 11.35 & 31.67 & 30.88 & 95.07 & 62.03 \\
\hline Sids 14 X Giza 171(1000) & 9.16 & 13.17 & 12.57 & 39.62 & 38.70 & 95.42 & 77.89 \\
\hline Sids 14 X Giza 171(2000) & 7.44 & 2.62 & 2.22 & 21.78 & 20.04 & 84.67 & 37.99 \\
\hline Gemmiza 11 (1000) & 10.00 & 10.00 & 9.43 & 31.62 & 30.72 & 94.37 & 61.47 \\
\hline Gemmiza 11 (2000) & 12.87 & 5.31 & 5.83 & 17.90 & 17.08 & 90.96 & 33.56 \\
\hline Sids 14 X Gemmiza 11 & 12.16 & 12.59 & 11.99 & 29.18 & 28.48 & 95.26 & 57.27 \\
\hline Sids 14 X Gemmiza11(1000) & 10.74 & 6.63 & 6.12 & 23.97 & 23.04 & 92.34 & 45.61 \\
\hline $\begin{array}{c}\text { Sids 14 X } \\
\text { Gemmiza11 }(2000)\end{array}$ & 11.35 & 8.18 & 7.65 & 25.21 & 24.32 & 96.82 & 57.27 \\
\hline \multicolumn{8}{|l|}{ 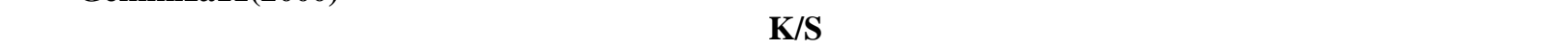 } \\
\hline Genotypes & mean & $\mathbf{V P}$ & VG & PCV & GCV & $\mathbf{h}_{\mathbf{b}}$ & GA \% \\
\hline Sids 14(1000) & 75.44 & 164.64 & 163.51 & 17.00 & 16.95 & 99.31 & 34.79 \\
\hline Sids 14(2000) & 76.43 & 172.66 & 171.51 & 17.19 & 17.13 & 99.33 & 35.18 \\
\hline Giza 171 (1000) & 75.99 & 65.98 & 65.08 & 10.69 & 10.61 & 98.63 & 21.72 \\
\hline Giza 171 (2000) & 66.79 & 97.76 & 96.77 & 14.80 & 14.72 & 98.98 & 30.18 \\
\hline Sids 14 X Giza 171 & 63.93 & 56.32 & 27.97 & 11.73 & 8.27 & 48.66 & 12.01 \\
\hline Sids 14 X Giza 171(1000) & 73.14 & 90.00 & 61.65 & 12.97 & 10.73 & 68.51 & 18.30 \\
\hline Sids 14 X Giza 171(2000) & 74.26 & 154.65 & 153.53 & 16.74 & 15.13 & 81.66 & 28.17 \\
\hline Gemmiza 11 (1000) & 72.79 & 109.96 & 108.94 & 14.40 & 14.33 & 99.06 & 29.40 \\
\hline Gemmiza 11 (2000) & 71.01 & 67.02 & 66.12 & 11.52 & 11.54 & 98.65 & 29.44 \\
\hline Sids 14 X Gemmiza 11 & 58.12 & 48.62 & 35.08 & 11.99 & 10.19 & 72.15 & 17.86 \\
\hline Sids 14 X Gemmiza11(1000) & 77.26 & 233.49 & 220.01 & 19.77 & 19.19 & 94.22 & 38.39 \\
\hline $\begin{array}{c}\text { Sids 14 X } \\
\text { Gemmiza11(2000) }\end{array}$ & 77.99 & 7.14 & 57.66 & 10.81 & 9.73 & 81.05 & 18.05 \\
\hline
\end{tabular}

Table 4. Continued. 
Scientific Journal of Agricultural Sciences 2 (2): 00-00, 2020

\begin{tabular}{|c|c|c|c|c|c|c|c|}
\hline \multirow{2}{*}{ Genotypes } & \multicolumn{7}{|c|}{$100-W g$} \\
\hline & mean & $\mathbf{V P}$ & VG & PCV & GCV & $\mathbf{h}_{\mathbf{b}}$ & GA\% \\
\hline Sids 14(1000) & 5.46 & 0.308 & 0.253 & 10.17 & 9.20 & 82.00 & 17.17 \\
\hline Sids 14(2000) & 4.86 & 0.190 & 0.146 & 8.96 & 7.86 & 77.07 & 14.23 \\
\hline G $171(1000)$ & 4.83 & 0.450 & 0.383 & 13.88 & 12.81 & 85.09 & 24.34 \\
\hline G 171 (2000) & 5.44 & 0.283 & 0.230 & 9.78 & 8.82 & 81.22 & 16.73 \\
\hline Sids 14 X G 171 & 4.43 & 0.316 & 0.259 & 12.68 & 11.50 & 82.21 & 21.48 \\
\hline Sids 14 X G 171(1000) & 5.02 & 0.517 & 0.445 & 14.31 & 13.28 & 86.10 & 25.39 \\
\hline Sids 14 X G 171(2000) & 5.47 & 0.402 & 0.339 & 11.59 & 10.64 & 84.23 & 20.11 \\
\hline Gem $11(1000)$ & 5.07 & 0.302 & 0.247 & 10.82 & 9.78 & 81.80 & 18.23 \\
\hline Gem 11 (2000) & 5.82 & 0.582 & 0.506 & 13.11 & 12.22 & 86.89 & 23.47 \\
\hline Sids 14 X Gem 11 & 5.35 & 0.363 & 0.303 & 11.25 & 10.27 & 84.41 & 19.33 \\
\hline Sids 14 X Gem 11(1000) & 4.91 & 0.388 & 0.326 & 12.68 & 11.62 & 83.95 & 21.93 \\
\hline Sids 14 X Gem 11(2000) & 5.63 & 0.540 & 0.467 & 13.05 & 12.13 & 86.40 & 23.22 \\
\hline Genotypes & mean & VP & VG & $\begin{array}{c}\text { S.Y/P } \\
\mathbf{P C V}\end{array}$ & GCV & $\mathbf{h}_{\mathbf{b}}$ & GA\% $\%$ \\
\hline Sids 14(1000) & 28.41 & 44.59 & 36.36 & 23.50 & 21.22 & 81.54 & 39.48 \\
\hline Sids 14(2000) & 29.25 & 138.05 & 125.82 & 40.16 & 38.94 & 94.03 & 77.80 \\
\hline G $171(1000)$ & 37.32 & 70.31 & 61.03 & 22.46 & 20.93 & 86.80 & 40.17 \\
\hline G $171(2000)$ & 34.16 & 94.91 & 86.68 & 28.51 & 27.25 & 91.32 & 53.64 \\
\hline Sids 14 X G 171 & 47.96 & 143.45 & 135.22 & 24.97 & 24.24 & 94.26 & 48.49 \\
\hline Sids 14 X G 171(1000) & 31.66 & 80.03 & 70.74 & 28.25 & 26.56 & 88.39 & 51.44 \\
\hline Sids 14 X G 171(2000) & 41.30 & 91.94 & 82.65 & 23.21 & 22.01 & 89.89 & 42.98 \\
\hline Gem $11(1000)$ & 32.99 & 62.44 & 57.87 & 23.34 & 23.04 & 92.25 & 45.66 \\
\hline Gem $11(2000)$ & 36.93 & 122.96 & 114.73 & 30.02 & 29.00 & 93.30 & 57.70 \\
\hline Sids 14 X Gem 11 & 36.13 & 64.61 & 59.98 & 22.24 & 21.43 & 92.83 & 42.53 \\
\hline Sids 14 X Gem 11(1000) & 34.30 & 94.78 & 90.15 & 28.38 & 27.68 & 95.11 & 55.61 \\
\hline Sids 14 X Gem 11(2000) & 41.91 & 143.14 & 138.51 & 28.54 & 28.08 & 96.76 & 55.71 \\
\hline
\end{tabular}

genetic gain from selection. In recent years the techniques of seed treatment with $\mathrm{HZ}$ have been greatly refined to give positive results for mutation programs. Besides, this chemical is easier to handle in the lab than irradiation. For these reasons $6 \mathrm{HZ}$ seed treatment should be recommended as an alternative to irradiation in inducing genetic variability for wheat breeding purposes.

\section{REFERENCE}

Abd El- Rady AG (2018). Genetic analysis of some agronomic traits in two bread wheat crosses under heat stress conditions. Journal .Plant production, Mansoura Univeristy., 9: 21-28.

Ahmad MS (2011). A new technique for induction of mutations in plant (induction of mutation in bread wheat) Egypt.J.Plant Breed(15) 2: 193-205.

Ahmad BH (2019). Induced mutations in some wheat ( Triticum aestivum L.) genotypes. Assiut Journal of Agriculture, 50(3): 27-38.

Al-Azab KhF (2013). Improving wheat for drought tolerance by using hybridization and mutation breeding Procedures.Ph.D.Thesis, Faculty. of Agriculture .Cairo Univeristy.,.Egypt.

Allard RW (1960). Principles of Plant Breeding. Jhon Wiley and Sons. Inc. New Yourk, 485.

Al-Shamma LMJ, Mohammed MH (2018). Induction of genetic variation in two varieties of wheat by electric and heat shock. Pak.J.Biotechnol. 15(2): 399-404.
Al-Shammaa LMJ (2014). Using chemical and physical mutagens for induction variation the quantitative and qualitative traits of three cultivars of Faba beans (Vicia fabe L.). Journal of Al- Nahrain University 17(1): 32-42.

Amin IA (2013). Genetic behavior of some agronomic traits in two durum wheat crosses under heat stress. Alexandria. Journal. Agriculture. 58 (1):53-66.

Balkan A (2018). Genetic variability, heritability and genetic advance for yield and quality traits in $\mathrm{M}_{2-4}$ generations of bread wheat (Triticum aestivum L.) genotypes.Turkish. Journal of .Field Crops., 23(2):173-179.

Brojevic K (1965). The effect of irradiation and selection after irradiation in the number of kernel per spike in wheat. Radation Botany, 5(SUPPL), 505513.

Burton GW (1952). Quantitative inheritance in grasses. Proc. $6^{\text {th }}$ Int. Grassland Cong., 1: 227-283.

Dhole VJ, Maheshwari JJ, Patil S (2003) Studies on mutations induced by EMS in soybean Glycine max Agricultural Science Digest, 23(3):226-228.

El-Aref KhAO, Tammam AM, Ibrahim MM, Koubisy YSI (2011).Generation mean analysis in bread wheat under drought conditions. Egypt Jurnal. Application. Sciences.,Vol. 26 (2), pp: 187-208.

El-Gammaal A A1, Yahya AI (2018). Genetic variability and heterosis in $F_{1}$ and $F_{2}$ generations of diallel crosses among seven Wheat genotypes. 
Journal. Plant Production, Mansoura University., 9 (12): 1075 - 1086.

Elmassry EL, Marwa M. El-Nahas (2018). Genetic behavior of some agronomic characters in three bread wheat crosses under different environmental conditions. Alexandria. Journal. Agriculture. Science. 63(5): 313-325.

FAO (2012). Food and Agriculture Organization of the United Nations (accessed 22 April 2012) .

Fatima KG, Al-Shamma LMJ (2015). Effect of chemical mutagenes on some morphological traits of Vicia faba L. Cv. Aqadulce. Iraqi Journal Of Science (56) 3:2506-2512.

Gupta VP, Virk DS (1997). Induced variation in segregating and homozygous populations of wheat. Ludhiana, India, 122-127.

Hanafy MS, Mohamed HA, Abd El-Hady EA (2006). The effect of low frequency electric field on the growth characteristics and the protein molecular structure of the wheat plant. Proceeding of the first scientific environmental conference, Zagazig Univ., $49-45$.

Hassan EE (1993). Gene action for yield and its attributes and their implications in bread wheat breeding. Zagazig.Journal. Agriculture. Research .vol.20(3), pp: 949 - 955 .

Hawash MM, Al-Shamma LMJ (2016). Effect of electric and heat shock on morphological characteristics for two varieties of wheat. Iraqi Journal Of Science (57) 2:1365-1370.

Johnson HW, Robinson HF, Comstock RE (1955). Estimates of genetic and environmental variability in soybean. Agron. J., 47 (7): 314-318.

Kashif M, Khaliq I (2004).Heritability, correlation and path coefficient analysis for some metric traits in Wheat. Int. J. Agri. Biol, 6(1):138- 142.

Khadr FH, Shukry MW (1972).Quantitative variability in wheat following irradiation, EMS and hybridization. Theoretical and Applied Genetics 42(4):174-180.

Khan MA, Verma RC (2015).Assesment of the effect of gamma radiations on various morphological and agronomic traits of common wheat (Triticum aestivum L.) var. WH-147. Euro. J.Exp. Bio., 5(7): 611.

Mahantashivayogayya K, Hanchinal RR, Salimath PM (2003). Variability studies of dicoccum wheat (Triticum dicoccum. Schrank Suhulb) following hybridization and hybridization followed by mutagenesis. Karnataka Journal of Agricultural Sciences. 16(4): 556-559.
Okaz AMA, Ahmad MSH, Sakr HGH (2016). Induced mutation in some safflower genotypes. Assiut J.Agric. Sci.,(47) No.(6-2)2016 (377-390).

Reddy VRK, Revathi R (1992). Introduction of chlorophyll mutants in triticale wheat and barley. New. Botanist, 19:1-4.

Robinson HF, Comstock RE, Harve PH (1949). Estimates of heritability and the degree of dominance in corn. Agron. J., 41 (8): 352-359.

Sakin MA (2002). The use of induced micromutations for quantitative characters after EMS and gamma ray treatments in durum wheat breeding. Pakistan Journal of Applied Sciences 2(12):11021107.

Sakin MA, Yildrim A (2004) .Induced the mutations for yield and its components in durum wheat (Triticum durum Desf.).Food Agriculture \& Environment ,(2): 285- 290.

Sarkar HK (1986). Induced variability of quantitative characters of wheat in M2 and M3 generations. Environment and Ecology. 725-729.

Shafey AS, Yassien HE, Abd- El- Moneim AM (1993). Genetic analysis of some plant characters, yield and its components in three wheat crosses. Annals of Agriculture. Science., Moshtohor , 31(4): 1889- 1904.

Singh BD (2000). Breeding for resistance to abiotic stresses. I. Drought resistance. Plant Breeding Principles and Methods. 381-409.

Singh U, Singh P (1975). Estimates of genetic and environmental variability in lentil (Lens esculenta, Moench.). Madras Agriculture. Journal., (9) :575578.

Sobieh El-SSS (1999). Improving grain yielding ability of six rarely tillering. wheat varieties through increasing spikes number per plant by using gamma rays. Zagazig J. Agric. Res. 26 (3A): 445-455

Sobieh EL-SSS, Ragab AI (2000). Gamma rays induced variability in bread wheat (Triticum aestivum L.). Seventh Conference of Arab J. of Nuclear Sci. and Applications 6-10 February, Cairo, Egypt.

Srivastava P, Marker S, Pandey P, Tiwari DK (2011). Mutagenic effects of sodium azide on the growth and yield characteristics in wheat (Triticum aestivum L.). Asian J. Plant Sci. 10(3), 190-201.

Zaazaa EI, Hager MA, El-Hashash EF (2012). Genetical analysis of some quantitative traits in wheat using six parameters genetic model. AmricanEurasian Journal. Agric. Environ. Sci.,12 (4): 456462. 
Scientific Journal of Agricultural Sciences 2 (2): 00-00, 2020

\section{مقارنة تأثير المطفر الكيميائى (هيدرازين هيدريت) والتهجين فى قمح الخبز}

\section{بركات حسن أحمد وحجاجى عبدالحفيظ أحمد}

قسم المحاصيل - كلية الزراعة - جامعة الأزهر بأسيوط

فى محاولة لإستنباط تراكيب وراثية من قمح الخبز عالية المحصول استخدم طريقتان هما التربية بالطفرات والتربية بالتهجين لإستحداث

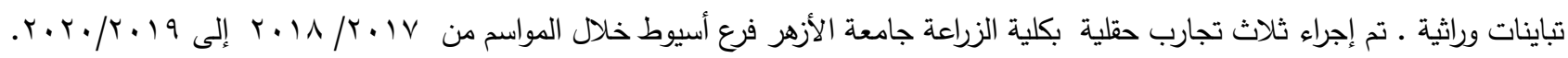
أكدت النتائج أن التهجين والمعاملة بالهيدرازين هيدرات بتركيز . . . ج جزء في المليون أفضل من استخدام المعاملة بالهيدرازين هيدرات بتركيز

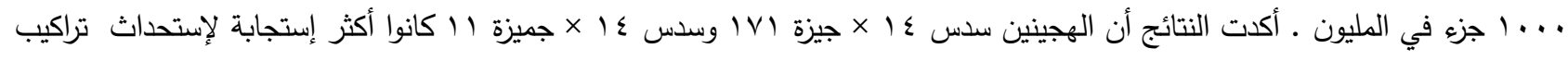
وراثية جديدة عن التراكيب الأخري فيما يتعلق بمحصول الحبوب على النبات .عثائر الجيل الثانى وعشائر الجيل الطفرى الثانى لهذه التراكيب

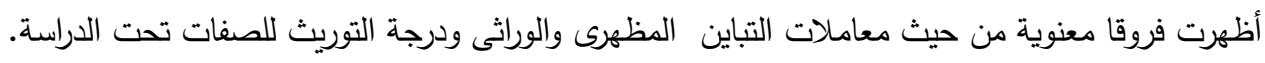

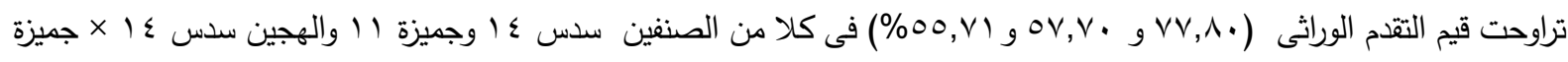

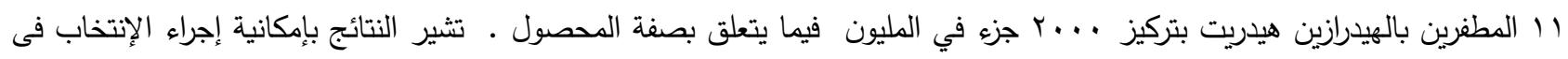

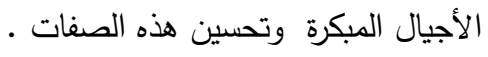

